\title{
A rare conditition: blackening of the hairs after stem cell transplantaion
}

\section{Hacer Gozde Gul*, Alı Erkurt M, Irfan Kuku and Emın Kaya}

Hematopoietic Stem Cell Transplantation Unit,Turgut Ozal Medicine Center, Inonu University, Malatya, Turkey

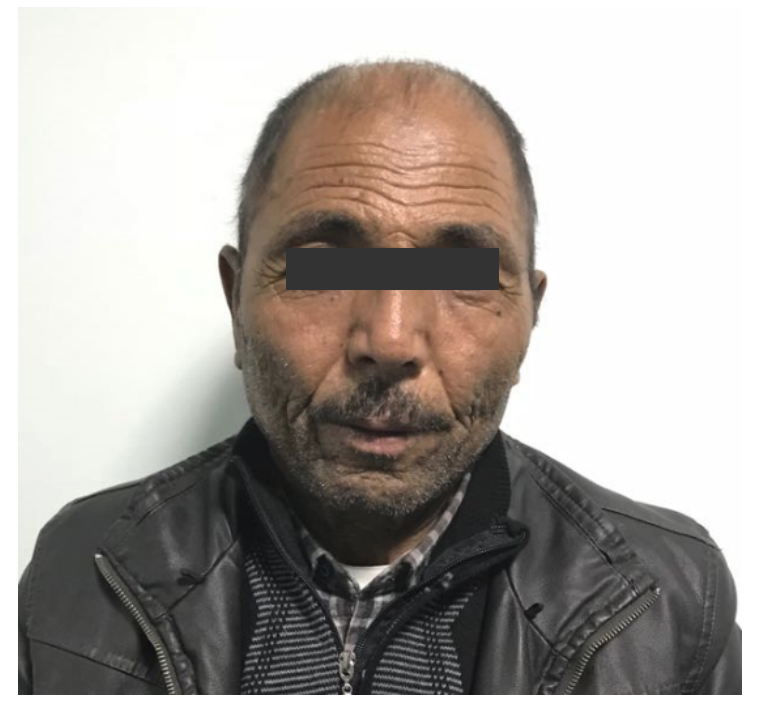

61 years old male patient. He was diagnosed with AML 4 years before. He was taken remission induction therapy and after he get allogeneic stem cell transplantation. He had graft versus host disease after the HSCT. He was taken for six months cyclosporine. He was taken imatinip anf mycofenolate mophetil also. Now he has not being used any drug for two years. The interesting point is his hair was White before the HSCT ,and now his hair is black even thoguh he has not being used any drug for 2 years.

Copyright: $(\mathrm{C} 2018 \mathrm{Gul} \mathrm{HG}$. This is an open-access article distributed under the terms of the Creative Commons Attribution License, which permits unrestricted use, distribution, and reproduction in any medium, provided the original author and source are credited.
*Correspondence to: Hacer gozde GUL, Hematopoietic Stem Cell Transplantation Unit,Turgut Ozal Medicine Center, Inonu University, Malatya, Turkey, Tel: 0422 341066 / 4203; Fax: 0422 3410728; E-mail: gozdegul44@hotmail.com

Received: August 29, 2018; Accepted: September 24, 2018; Published: October 06,2018 